\title{
Post-pandemic Community Resilience: Community and Economic Conditions of Wedi Village
}

\author{
Agustina J.N. Pramudita ${ }^{1} \&$ J.L. Eko Nugroho, \\ ${ }^{1}$ University of Surabaya, Surabaya, Indonesia \\ ${ }^{2}$ University of Surabaya, Surabaya, Indonesia \\ "Corresponding author. Email: jekonugroho@gmail.com
}

\begin{abstract}
This qualitative study aims to explore and understand the community, its economic conditions, and resilience towards the Covid-19 pandemic. The study was conducted at Wedi Village in Bojonegoro Regency, Indonesia. This village is well known for its small-medium enterprise products made from salak or snake fruit. Data collection was gathered through interviews and analyzed using community problem analysis methods and SWOT matrix, while the strategies analyzed using SWOT strategy matrix. The study shows that community involvement in programs and policy planning up to implementation is essential. Furthermore, networking and connection are also crucial in building the community's knowledge and capacity to be resilient.
\end{abstract}

Keywords: community involvement, community economy, resilience.

\section{INTRODUCTION}

These days, community and economic conditions are affected by the Covid-19 pandemic, especially in Indonesia. Having many populations makes Indonesia faces difficulties in maintaining various sectors, including the community and economic condition. Several development programs for communities were stopped due to the pandemic, while not all communities are ready to respond to the condition.

The economic data shows that Indonesia experienced a recession of 5.32 percent in Q1 2020 and only rose by 2.9 in the next quarter. Not only big companies but also small and medium-sized companies affected by the recession nationwide. Indonesia has been trying to assist and develop a more robust small-business sector to sustain the economy. With the fall of the global economy, it is essential to assess and develop economic resilience to survive.

The community can neutralize negative economic impacts if the community economy can retain, buffer, neutralize or internalize unsettling influences so that the extreme impact on the community economy is neutralized or rendered irrelevant (Briguglio et al. 2009). Therefore, community and economic conditions need to be learned and expanded even more.

Wedi village is located in Bojonegoro regency, East Java, Indonesia. Most of the villagers work as manufacturing company labor. Additionally, they are currently expanding their local products made of Salak fruit, called snake fruit. They have an abundance of raw materials and skills to make interesting products. This production activity is supported by the local nongovernment organization; hence it could be classified as small, medium-sized enterprises 
(SME). For quite some time, the community's SME received aid from the regency government and development programs from nearby universities to expand their production and marketing abilities.

Resilience has broad definitions or terminologies, depending on the context. Resilience can be viewed in a multilevel perspective, namely individual, family, smaller community, the broader community, and society resilience (Vella \& Pai 2019). In this paper, the types of resilience that will be discussed are economic resilience and community resilience. Economic resilience can be defined as the economy's ability to recover or adjust to the effects of shocks (Simmie \& Martin 2010). While community resilience refers to the ability of the social system to respond and recover from disasters and include a learning, adaptive process, and cope with the situation that enables the community's ability to reorganize and change (Cutter et al. 2008).

Resilience needs to be specified in order to understand the actual condition and stay in focus. In order to understand the resilience condition and future focus of the community, resilience needs to be specified into several terms. The terms can be defined as the resilience of what; resilience to what; resilience for who; and resilience for what (Dinh \& Pearson 2015). The resilience of what and for who refers to the community is where the economic system takes place. Resilience to what refers to what kind of disturbance the community experienced, which could be caused by natural disasters or policy changes. While resilience for what refers to the purpose of the system applied.

In order to understand the community's condition, there are several elements of community resilience as indicators, namely local knowledge, community network, communication, health, governance, resources, economic investment, preparedness, and mental outlook (Patel et al. 2017).

Local knowledge consists of 3 subelements. The first sub-element is training and education, which is a chance for a community member to receive an education and practice regarding disaster management. The second sub-element is factual knowledge which refers to general knowledge, information, and experience that the community members have. The third sub-element is collective efficacy and empowerment, which consist of shared belief in their ability to overcome the potential hardship.

Community networks and relationships also play an important role in resilience because a positive attitude during a crisis can be enabled when the members are well connected and cohesive. Not only a connection within the community but also with other communities. An effective communication and communication network are critical for resilience. Therefore, the community should form diverse communication methods and use common meanings to understand and provide opportunities for the community for open dialogue. After a disaster, the preexisting health of a community and conveyance of well-being administrations are critical for community resilience. Understanding and attention to health vulnerabilities can construct resilience before a disaster and moderate long-term issues after a disaster. Physical and psychological health is essential; hence it is critical to have high-standard facilities and services.

Governance and leadership shape how communities handle emergencies. There are two sub-elements inside governance and leadership: infrastructure and services and public involvement and support. The community's infrastructure and services, their adequacy, productivity, and capability to respond rapidly are highly critical. In order to have public involvement, it may include having local leaders who understand and represent a community's uniqueness and aspirations. Various resources have to be owned and widely available for the community to survive. There are several resource aspects: human, financial, natural, physical, and accessibility.

This research will explore understanding and answer several research questions, namely: What factors affect the community's economic resilience the most and why? 
What is the community's economic condition right now? And, What are the possible long-term and short-term plans to revive the economy and strengthen its resilience?

\section{RESEARCH METHODS}

This research is qualitative, using the phenomenology paradigm. The data for this research is obtained from semi-structured interviews with business owners in Wedi village, Bojonegoro Regency. Interview guides were laid out from the literature study and research questions. After all of the data gathered, a community analysis and SWOT Matrix (strengths, weaknesses, opportunities, and threats) analysis are conducted to sum up, all the necessary moves to enhance the community's resilience.

\section{RESULTS AND DISCUSSIONS}

\subsection{Community conditions}

The study listed several main aspects that can illustrate the community's conditions. Firstly, from a human capital aspect, there is a youngster's community inside Wedi village, which is usually called Karang $\mathrm{Ta}$ runa. The Karang Taruna members' age ranged from early teenagers to young adults. Most of its activities help secure the village and voluntarily help anything to do with crowd needs. Unfortunately, they never attend a proper development program regarding disaster management and SME management; therefore, they could not really help the community. Most of the Wedi villagers are high school leavers, and they have essential skills to make snake fruit products but lack knowledge on how to distribute the products and produce quality goods creatively.

Regarding the financial resources, some of the villagers have been able to manage their finances and have their backup money to continue their production activity for their SMEs. They previously also received financial aid from the government but were stopped since the Covid-19 pandemic. In fact, the village has plenty of natural resources to sustain their needs and raw materials for their snake fruit products. Infrastructures or physical resources in the Bojonegoro Regency are well and the government is still working on expanding the building into a more rural area. In general, the Regency already has an entirely public service facility, quite well distributed, and easily accessible from other Regency or city.

Diversity and economic investment in Wedi village are varied. Besides managing their own SMEs, the villagers' occupations are primarily in agriculture and manufacturing company labor. Hence during the Covid19 pandemic, they are mostly still sustained. Networking among community members and to other communities is not widely common; therefore, the villagers face some constraints in expanding their product distribution and information sharing about factual conditions. Governance and communication within the community are effective, but all decisions and activities are only based on central or Regency government command. Including the response to the pandemic and development programs that have been carried out in the community

\subsection{Problem Analysis}

Based on the data, the community is facing several problems. First, there are no assigned bureaus within the Wedi village community that take care of disaster management and response. While the community member itself is not yet skilled neither in disaster management nor SME management. All of the community activities are planned and conducted by the government program with a lack of public participation. Second, lack of knowledge and lack of networking limit the community members' skills in managing and distributing their SMEs products. It is mainly because they need more creative ideas, new information, and a robust management system. The government conducted several development programs in collabora- 
tion with several universities, but it was stopped due to the virus outbreak.

Behavior and environmental situations need to be changed in order to solve the problem. Centralization should be done less, encouraging more public participation in planning and conducting developmental programs; therefore, the community members will have a higher interest in leveling up their knowledge and skills and applying it into the community voluntarily.

Table 1. SWOT Matrix.

\begin{tabular}{|c|c|c|}
\hline & Helpful/Positive & Harmful/Negative \\
\hline \multirow[t]{5}{*}{ Internal } & Strengths & Weaknesses \\
\hline & $\begin{array}{l}\text { 1. Widely available } \\
\text { raw materials }\end{array}$ & $\begin{array}{l}\text { 1. Lack of skills \& } \\
\text { knowledge. }\end{array}$ \\
\hline & 2. Enthusiasm to & 2. Lack of creativity \\
\hline & learn & 3. Partnering takes time \\
\hline & $\begin{array}{l}\text { 3. Trust \& proximity } \\
\text { among members }\end{array}$ & $\begin{array}{l}\text { 4. More people should par- } \\
\text { ticipate }\end{array}$ \\
\hline \multirow[t]{4}{*}{ External } & Opportunities & Threats \\
\hline & 1. Popularity of & 1. Product competitors. \\
\hline & $\begin{array}{l}\text { SME products. } \\
\text { 2. Attention from }\end{array}$ & $\begin{array}{l}\text { 2. Termination of financial } \\
\text { aid from the government }\end{array}$ \\
\hline & $\begin{array}{l}\text { external organiza- } \\
\text { tions. }\end{array}$ & $\begin{array}{l}\text { 3. Government policy \& } \\
\text { programs regarding dis- } \\
\text { aster management \& re- } \\
\text { sponse }\end{array}$ \\
\hline
\end{tabular}

The leading cause of the problems is that community members are used to waiting for command and never being involved by the government in decision-making and program planning. The other leading cause is lack of networking and lack of knowledge regarding both disaster and SME management. It happens because the government does not push public participation, and there are only a few development and networking programs that are reachable by the community members. The conditions are also affected by personal and environmental factors of the community, mainly because of educational background and official policy.

Even though the community faces several problems, some forces drive the community to change. For example, there are plenty of Wedi village members that are willing to learn and develop their knowledge and skills. While the restraining forces include a lack of reachable development resources. The targets and agents of change to solve the problems are business owners in Wedi village, young community members, city gov- ernment, and third-party organizations (universities and developmental organizations).

Table 2. SWOT Strategies Matrix

\begin{tabular}{|c|c|c|}
\hline & Strengths & Weaknesses \\
\hline $\begin{array}{l}\text { Opportuni- } \\
\text { ties }\end{array}$ & $\begin{array}{l}\text { SO Strategies } \\
\text { 1. Creating up to } \\
\text { date product, fresh } \\
\text { design, \& market- } \\
\text { ing strategy } \\
\text { (S1,2;O1,2) } \\
\text { 2. Affiliating com- } \\
\text { munity members } \\
\text { \& external organi- } \\
\text { zations for educa- } \\
\text { tion }(\mathrm{S} 3, \text { O } 3)\end{array}$ & $\begin{array}{l}\text { WO Strategies } \\
\text { Creating a develop- } \\
\text { ment program on crea- } \\
\text { tivity, marketing \& } \\
\text { disaster management } \\
\text { in partnership with ex- } \\
\text { ternal organizations. } \\
\text { (W1,2,3; O1,2) }\end{array}$ \\
\hline Threats & $\begin{array}{l}\text { ST Strategies } \\
\text { Learning marketing } \\
\text { strategy, building } \\
\text { networking, disaster } \\
\text { management \& re- } \\
\text { silience (S1,2,3; } \\
\text { T1,3) }\end{array}$ & $\begin{array}{l}\text { WT Strategies } \\
\text { 1. Increasing financial } \\
\text { resources thorugh } \\
\text { sharing among the } \\
\text { community mem- } \\
\text { bers }(\mathrm{W} 1,2 ; \mathrm{T} 2) \\
\text { 2. Using government } \\
\text { authority to assign } \\
\text { disaster response } \\
\text { group (W4, T3) }\end{array}$ \\
\hline
\end{tabular}

\subsection{Discussion}

The findings show that the Wedi village community could make several changes to transform and solve their problems. First, the government needs to change its ways of planning. They need more public support and involvement. If this situation occurs, local interest in expanding their skills and knowledge will also increase. This condition happens because the government will get public perspective, needs, and uniqueness. When the community members are interested, the government can affiliate with external organizations to conduct several programs based on the community's needs.

Afterward, the government can assign or form smaller groups responsible for the community's disaster management and SME management. Those groups' members are already trained and skilled; therefore, they can teach and educate more people in the community.

Second, the programs that will be conducted must answer the community's needs, teach the theories, implement and expand the members' networking. Needs that should be covered are related to creativity, financial management, disaster response and management, and networking. External organiza- 
tions such as universities can help because they have a significant connection with people in various sectors. This networking can also increase understanding in many aspects of needs.

This finding is supported by previous studies that reveal having a high formal education is less important than creativity and talent in developing a business and entrepreneurship (Oke et al. 2009, Van Den Broek et al. 2008). Therefore, though not many community members have high education, they can still learn and develop their SME. Mentoring is one way of developing programs that could provide some practical skills (Loh \& Dahesihsari 2013). Through good networking, mentors could be found everywhere.

\section{CONCLUSION}

After conducting this research, it is found that the main problems of the Wedi village community are lack of knowledge and a government that is too centralized. These conditions can be solved through several methods. First, by carrying out a development program in collaboration with external organizations that involve community members' thoughts and ideas during planning and implementation. Second, the government should assign a disaster response group for the community in their regency.

\section{REFERENCES}

Briguglio, L., Cordina, E., Farrugia, N., \& Vella, S. 2009. Economic vulnerability and resilience: Concepts and measurements. Oxford Development Studies 37: 229-247

Cutter, S.L., Barnes, L., Berry, M., Burton, C.G., Evans, E., Tate, E.C. \& Webb, J. 2008. Community and regional resilience: Perspective of hazards, disasters, and emergency management. CARRI Research Report 1 Community and Regional Resilience Institute, Oak Ridge, TN.

Dinh, H. \& Pearson, L. 2015. Specifying community economic resilience: A framework for measurement. Australian Journal of Regional Studies 21: 101-125.
Loh, J. \& Dahesishsari, R. 2013. Resilience and economic empowerment: A qualitative investigation of entrepreneurial Indonesian Women. Journal of Enterprising Culture 21(1): 107-121.

Oke, A., Munshi, N. \& Walumbwa, F. 2009. The influence of leadership on innovation processes and activities. Organizational Dynamics 38: 64-72

Patel, S.S., Amlot, R. \& Rubin, G.J. 2017. What do we mean by 'Community Resilience'? A systematic literature review of how it is defined in the literature. PLOS Currents Disasters.

Simmie, J. \& Martin, R. 2010. The economic resilience of regions: Towards an evolutionary approach. Cambridge Journal of Regions. Economy, and Society 3: 27-43

Van den Broek, H., Cools, E. \& Maenhout, T. 2008. A case study of art economy: Building bridges between art and enterprise: Belgian businesses stimulate creativity and innovation through art. Journal of Management and Organization 14: 573-587

Vella, S.L. \& Pai, N.B. 2019. A theoretical review of psychological resilience: Defining resilience and resilience research over decades. Archive of Medicine Health Sciences 7(2): 233-239. 